REVISTA Hed 24(2): 5-10, 2016

EDITORIAL

\title{
EL ARTÍCULO CIENTÍFICO: IMPACTO Y VISIBILIDAD
}

\author{
WILSON BAUTISTA MOLANO MD, PhD(c) \\ Internista, Reumatólogo \\ Editor Revista MED, Facultad de Medicina \\ Universidad Militar Nueva Granada \\ wilson.bautista@unimilitar.edu.co
}

La experiencia como autor de varios artículos en revistas tanto nacionales como internacionales junto con el acompañamiento realizado en la revista MED, me han permitido comprender en detalle la importancia que tienen los manuscritos en la difusión y socialización del conocimiento científico. Sin embargo, esta circunstancia me ha permitido observar que en ocasiones artículos que llegan al Comité Editorial y que incluso son evaluados por pares, carecen de la estructura exigida a un artículo de investigación. En muchas ocasiones, los manuscritos que no son considerados para publicación, tiene dificultad para expresar con claridad el contenido y mensaje del trabajo de investigación y además no presentan suficiente coordinación y equilibrio entre sus partes. Consciente de la existencia de un gran volumen de información y bibliografía en la literatura, el presente documento pretende enfatizar en la importancia que representa la óptima redacción y organización estructural que deben tener los autores cuando desean dar a conocer los resultados de sus trabajos a través de nuestra revista.

Existen múltiples definiciones de artículo científico. Sin entrar en definiciones conceptuales y nosológicas, es ampliamente aceptada la siguiente definición: es un documento escrito que describe y presenta de manera clara y precisa los resultados originales de una investigación ya realizada sobre un área determinada del conocimiento. Su principal característica radica en el hecho de que refleja un avance en el conocimiento y por lo tanto solo puede cumplir su objetivo cuando ha sido publicado y puesto a disposición y revisión por parte de la comunidad científica para que pueda ser incorporado por sus pares. De esta forma, el artículo científico ya publicado puede tener impacto entre la comunidad científica del área específica del conocimiento. En el medio académico el artículo científico busca fomentar el desarrollo de métodos experimentales e innovadores entre los investigadores y estimular al personal en entrenamiento a participar en estos procesos especialmente en la redacción de los mismos.

Teniendo en cuenta lo anterior, un manuscrito original debe ser un documento que ofrezca la suficiente información para que los lectores y revisores puedan conocer el objetivo del trabajo de investigación y en el cual se describa en forma detallada la forma como este trabajo fue realizado. Así mismo, debe incluir un análisis profundo y académico de los resultados, sus implicaciones en el área de conocimiento, comparación e interpretación con estudios similares, discrepancia con otros resultados ya publicados y finalmente es necesario que describa el aporte que representa el trabajo.

La Revista MED como órgano de divulgación científico y académico de la Facultad de Medicina de la Universidad Militar Nueva Granada, continuara promoviendo la difusión del conocimiento de la comunidad científica nacional e internacional en el área de la Medicina y Ciencias de la Salud, manteniendo altos estándares de gestión editorial con el objeto de publicar manuscritos de alto rigor académico y que reflejen aportes en el área médica. Por lo tanto, hacemos extensiva la invitación a los autores interesados en enviarnos sus manuscritos originales de investigación científica o tecnológica para que sean postuladas para publicación en la Revista MED a través del siguiente vínculo:

http://revistas.unimilitar.edu.co/index.php/rmed/about/submissions\#onlineSubmissions 


\title{
EDITORIAL
}

\section{THE SCIENTIFIC ARTICLE: IMPACT AND VISIBILITY}

\author{
WILSON BAUTISTA MOLANO MD, PhD (c)
}

\author{
Internist, Rheumatologist \\ Editor Scientific research journal \\ Facultad de Medicina \\ Universidad Militar Nueva Granada
}

The experience as an author of several articles in national and international journals together with the accompaniment carried out in MED magazine has allowed me to understand in detail the importance of manuscripts in the dissemination and socialization of scientific knowledge. However, this circumstance has allowed me to observe that sometimes articles that arrive at the Editorial Committee and that even are evaluated by pairs, lack the structure required to a research article. In many cases, manuscripts that are not considered for publication have difficulty expressing clearly the content and message of the research work and also do not present sufficient coordination and balance between their parts. Aware of the existence of a large volume of information and bibliography in the literature, this document intends to emphasize the importance of the optimal drafting and structural organization that the authors should have when they want to present the results of their work through Our magazine.

There are multiple definitions of scientific articles. Without entering into conceptual and nosological definitions, the following definition is widely accepted. Is a written document that describes and presents in a clear and precise way the original results of an investigation already carried out on a certain area of knowledge. Its main characteristic lies in the fact that it reflects an advance in knowledge and therefore can only fulfill its purpose when it has been published and made available and reviewed by the scientific community so that it can be incorporated by its peers. In this way, the scientific article already published can have an impact among the scientific community in the specific area of knowledge. In the academic environment, the scientific article seeks to encourage the development of experimental and innovative methods among researchers and to motivate the personnel in training to participate in these processes especially in the writing of the same ones.

Taking into account the above, an original manuscript should be a document that provides sufficient information so that readers and reviewers can know the purpose of the research work and in which the details of how this work was performed are described in detail. It should also include a deep and academic analysis of the results, their implications in the area of knowledge, comparison and interpretation with similar studies, discrepancy with other published results and finally it is necessary to describe the contribution that represents the work.

MED Magazine as a scientific and academic dissemination body of the Faculty of Medicine of the New Granada Military University will continue to promote the dissemination of the knowledge of the national and international scientific community in the area of Medicine and Health Sciences, maintaining high standards Of editorial management in order to publish manuscripts of high academic rigor and that reflect contributions in the medical area.

Therefore we extend the invitation to authors interested in sending us their original manuscripts of scientific or technological research to be postulated for publication in MED Magazine through the following link:

http://revistas.unimilitar.edu.co/index.php/rmed/about/submissions\#onlineSubmissions 


\title{
NOTA DO EDITOR
}

\section{ARTIGO CIENTÍFICO: O IMPACTO EA VISIBILIDADE}

\author{
WILSON BAUTISTA MOLANO MD, PhD (c) \\ Internista, Reumatologista \\ Editor Jornal de investigação científica \\ Faculdade de Medicina \\ Universidade Militar de Nova Granada
}

A experiência como autor de vários artigos em revistas nacionais e internacionais, juntamente com o acompanhamento realizado na revista MED, permitiu-me compreender em detalhes a importância dos manuscritos na divulgação e socialização do conhecimento científico. No entanto, essa circunstância me permitiu observar que, por vezes, artigos que chegam ao Comitê Editorial e que até são avaliados por pares, carecem da estrutura necessária para um artigo de investigação. Em muitos casos, os manuscritos que não são considerados para publicação têm dificuldade em expressar claramente o conteúdo e a mensagem do trabalho de investigação e também não apresentam coordenação e equilíbrio suficientes entre suas partes. Consciente da existência de um grande volume de informações e bibliografia na literatura, este documento pretende enfatizar a importância da ótima redação e organização estrutural que os autores devem ter quando desejam apresentar os resultados de seu trabalho através da revista Nossa.

Existem várias definições de artigos científicos. Sem entrar em definições conceituais e nosológicas, a seguinte definição é amplamente aceita: É um documento escrito que descreve e apresenta de forma clara e precisa os resultados originais de uma investigação já realizada em determinada área do conhecimento. Sua característica principal reside no fato de que ela reflete um avanço no conhecimento e, portanto, só pode cumprir seu propósito quando foi publicado e disponibilizado e revisto pela comunidade científica para que possa ser incorporado por seus pares. Desta forma, o artigo científico já publicado pode ter um impacto entre a comunidade científica na área específica do conhecimento. No âmbito acadêmico, o artigo científico busca incentivar o desenvolvimento de métodos experimentais $e$ inovadores entre investigação e motivar pessoal em treinamento a participar desses processos, especialmente na redação dos mesmos.

Tendo em conta o que precede, um manuscrito original deve ser um documento que forneça informações suficientes para que os leitores e revisores possam conhecer a finalidade do trabalho de pesquisa e em que os detalhes de como este trabalho foi realizado são descritos em detalhes. Deve também incluir uma análise profunda e acadêmica dos resultados, suas implicações na área de conhecimento, comparação e interpretação com estudos semelhantes, discrepância com outros resultados publicados e, finalmente, é necessário descrever a contribuição que representa o trabalho.

MED Magazine como um corpo de divulgação científica e acadêmica da Faculdade de Medicina da Universidade Militar de Nova Granada continuará a promover a divulgação do conhecimento da comunidade científica nacional e internacional na área de Medicina e Ciências da Saúde, mantendo altos padrões de editorial A fim de publicar manuscritos de alto rigor acadêmico e que reflitam contribuições na área médica.

Portanto, estendemos o convite aos autores interessados em nos enviar seus manuscritos originais de pesquisa científica ou tecnológica a serem postulados para publicação na Revista MED através do seguinte link:

http://revistas.unimilitar.edu.co/index.php/rmed/about/submissions\#onlineSubmissions 